\title{
GAMBARAN PARTISIPASI MASYARAKAT \\ DALAM JAMINAN KESEHATAN MASYRAKAT (JKN) \\ DI DUSUN PAMENGPEUK DESA CIKUNIR KECAMATAN SINGAPARNA \\ KABUPATEN TASIKMALAYA TAHUN 2018
}

OLEH :

\author{
Dadan Yogaswara, S.KM,M.KM \\ danyogas@yahoo.com \\ Ade Rahmat \\ STIKes Respati
}

\section{A. ABSTRAK}

Peserta Jaminan Kesehatan Nasional (JKN) di Provinsi Jawa Barat pada tahun 2015 baru mencapai $68.63 \%$ yang meliputi Penerima Bantuan Iuran (PBI) APBN 31,44\%, PBI APBD 5,16\%, Pekerja Penerima Upah (PPU) 15,58\%, Pekerja Bukan Penerima Upah (PBPU)/mandiri 11,15\%, Bukan Pekerja (BP) 2,01\% dan Jaminan Kesehatan Daerah 3,26\% (Profil Kesehatan Jawa Barat tahun 2017:92). Tujuan Penelitian : untuk mengetahui gambaran partisipasi masyarakat dalam Jaminan Kesehatan Masyrakat (JKN) di Dusun Pamengpeuk Desa Cikunir Kecamatan Singaparna Kabupaten Tasikmalaya tahun 2018.

Jenis penelitian yang digunakan adalah kuantitatif dengan desain deskriptif. Populasi dalam penelitian ini adalah seluruh kepala keluarga di wilayah Dusun Pamengpeuk sebanyak 107 orang. Tehnik samping adalah total sampling. Variabel yang diteliti adalah partisipasi kelapa keluarga dalam Jaminan kesehatan Nasional. Instrumen yang digunakan adalah kuesioner. Analisis yang digunakan adalah analisis univariat.

Hasil penelitian menyatakan bahwa Responden yang memiliki JKN sebanyak 73 responden (68.3\%) dan yang tidak memiliki JKN sebanyak 34 responden (31.7\%). Jenis JKN yang digunakan responden yaitu BPJS sebanyak 51 responden (47,7\%), KIS 17 responden (15,9\%), lainnya sebanyak 5 responden (4,7\%) dan yang tidak memiliki JKN sebanyak 34 responden $(31,7 \%)$.

Rekomendasi penelitian : responden pada penelitian ini mayoritas mempunyai JKN akan tetapi masih ada responden yang tidak memilki JKN, sehingga instansi kesehatan dapat bekerjasama dengan pihak BPJS kesehatan untuk melaksanakan sosialisasi untuk meningkatkan cakupan kepesertaan JK

\section{Kata kunci : Partisipasi, Jaminan Kesehatan Nasional}

\section{B. PENDAHULUAN}

Sejak awal diluncurkan program JKNKIS pada tahun 2014, cakupan kepesertaan program terus meningkat. Proporsi kepesertaan terbanyak berasal dari segmen PBI (APBN) sebesar 49,10\% pada tahun 2017), walaupun proporsi PBI dari seluruh peserta JKN menurun setiap tahunnya, menunjukkan peningkatan kepesertaan dari segmen Non-PBI. Kepesertaan JKN KIS mengalami peningkatan sejak tahun 2014, pada akhir 2014 tercatat kepesertaan sebanyak 133,4 juta jiwa dan terus meningkat sampai dengan akhir tahun 2017 mencapai 187,9 juta jiwa (Profil Kesehatan Indonesia: 2018:99).

Peserta Jaminan Kesehatan Nasional (JKN) di Provinsi Jawa Barat pada tahun 2015 baru mencapai $68.63 \%$ yang meliputi Penerima Bantuan Iuran (PBI) APBN $31,44 \%$, PBI APBD 5,16\%, Pekerja Penerima Upah (PPU) 15,58\%, Pekerja Bukan Penerima Upah (PBPU)/mandiri $11,15 \%$, Bukan Pekerja (BP) $2,01 \%$ dan 
Jaminan Kesehatan Daerah 3,26\% (Profil Kesehatan Jawa Barat tahun 2017:92).

Menurut hasil penelitian Purwaningsih (2016) menyatakan bahwa faktor-faktor yang berhubungan dengan keikutsertaan kepala keluarga dalam JKN yaitu: pengetahuan,sikap, informasi yang diperoleh kepala keluarga, dukungan keluarga dan penghasilan.

Berdasarkan hasil penelitian Suhardi dkk (2014) menyatakan bahwa faktor-faktor yang berhubungan dengan kemauan masyrakat menjadi peserta JPKM Mandiri di wilayah Kota Salatiga yaitu: Ability To Pay, Willingness To Pay, Pengetahuan, Sikap terhadap asuransi kesehatan (JPKM Mandiri), keuntungan menjadi peserta asuransi kesehatan (JPKM Mandiri), dukungan keluarga dan dukungan tokoh masyrakat/ tokoh agama berhubungan. Faktor yang paling dominan mempengaruhi kemauan masyrakat menjadi peserta JPKM Mandiri di wilayah Kota Salatiga yaitu dukungan tokoh masyarakat/ tokoh agama.

Hasil penelitian Kurniawati dan Rachmawati (2018) menyatakan bahwa penyebab rendahnya kepemilikan kartu JKN dibedakan menjadi penyebab yang dapat ditangani (manageable) yang terdiri dari rendahnya pengetahuan masyarakat, kurangnya sosialisasi, kurangnya media promosi kesehatan dan kepala keluarga kurang menyadari pentingnya JKN. Sedangkan penyebab yang tidak dapat ditangani (unmanageable) yakni pendidikan masyarakat yang rendah.

Berdasarkan uraian tersebut peneliti tertarik untuk meneliti gambaran partisipasi masyarakat dalam Jaminan Kesehatan Masyrakat (JKN) di Dusun Pamengpeuk Desa Cikunir Kecamatan Singaparna Kabupaten Tasikmalaya tahun 2018. Tujuan Penelitian : untuk mengetahui gambaran partisipasi masyarakat dalam Jaminan Kesehatan Masyrakat (JKN) di Dusun Pamengpeuk Desa Cikunir Kecamatan Singaparna Kabupaten Tasikmalaya tahun 2018 .

\section{METODOLOGI PENELITIAN}

Jenis penelitian yang digunakan adalah kuantitatif dengan desain deskriptif. Populasi dalam penelitian ini adalah seluruh kepala keluarga di wilayah Dusun Pamengpeuk sebanyak 107 orang. Tehnik samping adalah total sampling. Variabel yang diteliti adalah partisipasi kelapa keluarga dalam Jaminan kesehatan Nasional. Instrumen yang digunakan adalah kuesioner. Analisis yang digunakan adalah analisis univariat.

\section{HASIL PENELITIAN}

\section{Karakteristik Responden}

a. Distribusi Responden Berdasarkan Kelompok Umur

Distribusi responden berdasarkan kelompok umur di Dusun Pameungpeuk dapat dilihat pada tabel 5.1 .1 berikut ini:

Tabel 5.1.1 Distribusi Responden Berdasarkan Kelompok Umur

\begin{tabular}{|l|c|r|r|r|r|l|l|l|}
\hline \multirow{2}{*}{ No } & \multirow{4}{*}{ Kelompok umur } & \multicolumn{9}{|l|}{$\mathbf{R W}$} & \multirow{2}{*}{ F } & \multirow{2}{*}{$\%$} \\
\cline { 2 - 8 } & & $\mathbf{0 0 5}$ & $\mathbf{0 0 6}$ & $\mathbf{0 0 7}$ & $\mathbf{0 0 8}$ & $\mathbf{0 1 3}$ & & \\
\hline 1 & $20-24$ Tahun & 0 & 1 & 0 & 1 & 0 & 2 & 1,9 \\
\hline 2. & $25-29$ Tahun & 0 & 4 & 1 & 5 & 3 & 13 & 12,1 \\
\hline 3. & $30-34$ Tahun & 1 & 4 & 5 & 7 & 1 & 18 & 16,8 \\
\hline 4. & 35-39 Tahun & 2 & 3 & 4 & 7 & 2 & 18 & 16,8 \\
\hline 5. & 45-49 Tahun & 2 & 4 & 2 & 1 & 6 & 15 & 14,0 \\
\hline 6. & $50-54$ Tahun & 1 & 1 & 2 & 1 & 5 & 10 & 9,3 \\
\hline 7. & $55-59$ Tahun & 1 & 5 & 4 & 1 & 3 & 13 & 12,1 \\
\hline
\end{tabular}




\begin{tabular}{|l|c|c|c|c|c|l|l|l|}
\hline 8. & 60-64 Tahun & 2 & 2 & 2 & 0 & 2 & 8 & 7,5 \\
\hline 9. & 70-74 Tahun & 1 & 1 & 3 & 0 & 0 & 5 & 4,7 \\
\hline 10. & 75-79 Tahun & 3 & 0 & 1 & 0 & 0 & 4 & 3,7 \\
\hline \multicolumn{2}{|r|}{ Total } & $\mathbf{1 3}$ & $\mathbf{2 5}$ & $\mathbf{2 4}$ & $\mathbf{2 3}$ & $\mathbf{2 2}$ & $\mathbf{1 0 7}$ & $\mathbf{1 0 0}$ \\
\hline
\end{tabular}

Berdasarkan tabel 5.1.1 dapat diketahui bahwa mayoritas responden berdasarkan kelompok umur yaitu 30-39 sebanyak 18 responden $(33,6 \%)$.

\section{b. Distribusi Responden Berdasarkan Jenis Kelamin}

Distribusi responden berdasarkan jenis kelamin di Dusun Pameungpeuk dapat dilihat pada tabel 5.1 .2 berikut ini:

Tabel 5.1.2 Distribusi Responden Berdasarkan Jenis Kelamin

\begin{tabular}{|l|l|c|c|}
\hline No & Jenis Kelamin & Frekuensi & $\%$ \\
\hline 1. & Laki-laki & 16 & 14.9 \\
\hline 2. & Perempuan & 91 & 85.1 \\
\hline Jumlah & 107 & 100 \\
\hline
\end{tabular}

Berdasarkan tabel 5.1.2 dapat diketahui bahwa mayoritas responden berjenis kelamin perempuan sebanyak 91 responden $(85,1 \%)$.

\section{Distribusi Responden Berdasarkan Kepemilikan JKN}

Distribusi responden berdasarkan jenis kelamin di Dusun Pameungpeuk dapat dilihat pada tabel 5.2 berikut ini:

Tabel 5.2 Distribusi Responden Berdasarkan Kepemilikan JKN

\begin{tabular}{|l|l|l|l|}
\hline No & Kepemilikan JKN & Frekuensi & \% \\
\hline 1. & Ya & 73 & 68.3 \\
\hline 2. & Tidak & 34 & 31.7 \\
\hline & Jumlah & $\mathbf{1 0 7}$ & $\mathbf{1 0 0}$ \\
\hline
\end{tabular}

Berdasarkan tabel 5.2 dapat diketahui bahwa responden yang memiliki JKN sebanyak 73 responden $(68.3 \%)$ dan yang tidak memiliki JKN sebanyak 34 responden $(31.7 \%)$.

\section{Distribusi Responden Berdasarkan Jenis JKN}

Distribusi responden berdasarkan jenis JKN di Dusun Pameungpeuk dapat dilihat pada tabel 5.3 berikut ini:

Tabel 5.3 Distribusi Responden Berdasarkan Jenis JKN

\begin{tabular}{|l|l|l|l|}
\hline No & Jenis JKN & Frekuensi & \% \\
\hline 1. & BPJS & 51 & 47.7 \\
\hline 2. & KIS & 17 & 15.9 \\
\hline
\end{tabular}




\begin{tabular}{|l|l|l|l|}
\hline 3. & Lainnya & 5 & 4.7 \\
\hline 4. & Tidak ada & 34 & 31.7 \\
\hline \multicolumn{2}{|c|}{ Jumlah } & $\mathbf{1 0 7}$ & $\mathbf{1 0 0}$ \\
\hline
\end{tabular}

Berdasarkan tabel 5.3 dapat diketahui bahwa jenis JKN yang digunakan responden yaitu BPJS sebanyak 51 responden $(47,7 \%)$, KIS 17 responden $(15,9 \%)$, lainnya sebanyak 5 responden $(4,7 \%)$ dan yang tidak memiliki JKN sebanyak 34 responden $(31,7 \%)$.

\section{E. PEMBAHASAN}

Jaminan sosial adalah salah satu bentuk perlindungan sosial untuk menjamin seluruh rakyat agar dapat memenuhi kebutuhan dasar hidupnya yang layak ( UU No 24 Tahun 2011).

Berdasarkan hasil penelitian menunjukan bahwa dari 107 responden, responden yang memiliki JKN sebanyak 73 responden $(68.3 \%)$ dan yang tidak memiliki JKN sebanyak 34 responden (31.7\%). Jenis JKN yang digunakan responden yaitu BPJS sebanyak 51 responden $(47,7 \%)$, KIS 17 responden $(15,9 \%)$, lainnya sebanyak 5 responden $(4,7 \%)$ dan yang tidak memiliki JKN sebanyak 34 responden (31,7\%).

Hasil penelitian Kurniawati dan Rachmawati (2018) menyatakan bahwa penyebab rendahnya kepemilikan kartu JKN dibedakan menjadi penyebab yang dapat ditangani (manageable) yang terdiri dari rendahnya pengetahuan masyarakat, kurangnya sosialisasi, kurangnya media promosi kesehatan dan kepala keluarga kurang menyadari pentingnya JKN. Sedangkan penyebab yang tidak dapat

\section{F. SIMPULAN DAN SARAN}

1. Simpulan

7.1.1 Responden yang memiliki JKN sebanyak 73 responden $(68.3 \%)$ dan yang tidak memiliki JKN sebanyak 34 responden $(31.7 \%)$.

7.1.2 Jenis JKN yang digunakan responden yaitu BPJS sebanyak 51 responden $(47,7 \%)$, KIS 17 responden $(15,9 \%)$, lainnya sebanyak 5 responden $(4,7 \%)$ dan yang tidak memiliki JKN sebanyak 34 responden $(31,7 \%)$. ditangani (unmanageable) yakni pendidikan masyarakat yang rendah.

Menurut hasil penelitian Suhardi dkk (2014) menyatakan bahwa faktor-faktor yang berhubungan dengan kemauan masyrakat menjadi peserta JPKM Mandiri di wilayah Kota Salatiga yaitu: Ability To Pay, Willingness To Pay, Pengetahuan, Sikap terhadap asuransi kesehatan (JPKM Mandiri), keuntungan menjadi peserta asuransi kesehatan (JPKM Mandiri), dukungan keluarga dan dukungan tokoh masyrakat/ tokoh agama berhubungan. Faktor yang paling dominan mempengaruhi kemauan masyrakat menjadi peserta JPKM Mandiri di wilayah Kota Salatiga yaitu dukungan tokoh masyarakat/ tokoh agama.

Berdasarkan uraian tersebut dapat diketahui bahwa responden pada penelitian ini mayoritas mempunyai JKN akan tetapi masih ada responden yang tidak memilki JKN, sehingga instansi kesehatan dapat bekerjasama dengan pihak BPJS kesehatan untuk melaksanakan sosialisasi untuk meningkatkan cakupan kepesertaan JKN

\section{Saran}

a. Bagi Masyarakat

Mengikuti kegiatan sosialisasi dengan baik, untuk meningkatkan pengetahuan mengenai manfaat yang akan diperoleh dari adanya JKN.

b. Bagi Instansi Kesehatan Instansi kesehatan dapat bekerjasama dengan pihak BPJS kesehatan untuk melaksanakan sosialisasi untuk meningkatkan cakupan kepesertaan JKN di Dusun Pamengpeuk. 
c. Bagi Instansi Pendidikan

Meningkatkan keilmuan dan teknologi untuk ikut berkontribusi dalam menyelesaikan masalah kesehatan.

\section{G. DAFTAR PUSTAKA}

Dinkes Jabar. (2017). Profil Kesehatan Jawabarat Tahun 2016. Dinas kesehatan Jawa Barat:Bandung

Hajar dkk. (2018). Pemberdayaan dan Partisipasi Masyarakat Pesisir. Lembaga Penelitian dan Penulisan Ilmiah Aqli: Medan

Kemenkes RI. (2018). Profil Kesehatan Indonesia Tahun 2017. Kementrian Kesehatan Republik Indonesia. Jakarta

Kurniawati dan Rachmawati.(2018). Identifikasi Penyebab Rendahnya Kepesertaan Jkn Pada Pekerja Sektor Informal Di Kawasan Pedesaan.Jurnal Administrasi Kesehatan Indonesia. 6(1)

Laporan Praktek Belajar Lapangan. STIKes Respati: Tasikmalaya

Permenkes Nomor 28 tahun 2014 tentang Pedoman pelaksanaan program jaminan kesehatan nasional

Purwaningsih, S.B. (2016). Faktor-faktor yang berhubungan dengan keikutsertaan masyarakat dalam jaminan kesehatan nasional di Desa Tegalsari Kabupaten Ponorogo2015. Skripsi: Universitas Muhamadiyah Surakarta

Puspitasari, Y. (2017). Faktor yang mempengaruhi partisipasi kepesertaan jaminan kesehatan nasional pada pekerja bukan penerima upah di Desa Kaisyan Timur Wilayah Kerja Puskesmas Kaisyah Kabupaten Jember.Skripsi: Universitas Jember

Suhardi dkk. (2014). Analisis faktor-faktor yang berpengaruh terhadap kemauan masyarakat menjadi peserta JPKM mandiri di wilayah Kota Salatiga. Jurnal Promosi Kesehatan Indonesia. 9 (1).

UU No 24 tahun 2011 tentang Badan Penyelenggara Jaminan Sosial 